\title{
Rat C peptide I and II stimulate glucose utilization in STZ-induced diabetic rats
}

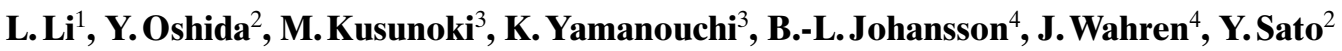 \\ ${ }^{1}$ First Division of Health Promotion Science, Graduate School of Medicine, Nagoya University, Furo-cho, Chikusa-ku, \\ Nagoya, Japan \\ ${ }^{2}$ Research Centre of Health, Physical Fitness and Sports, Nagoya University, Furo-Cho, Chikusa-ku, Nagoya, Japan \\ ${ }^{3}$ First Department of Internal Medicine, Aichi Medical University, Nagakute, Aichi, Japan \\ ${ }^{4}$ Department of Clinical Physiology, Karolinska Hospital, Stockholm, Sweden
}

\section{Abstract}

Aims. To study the effects of physiological concentrations of rat proinsulin C peptide I and II, respectively, on whole body glucose utilization in streptozotocin diabetic and healthy rats.

Methods. A sequential insulin clamp procedure was used (insulin infusion rates 3.0 and $30.0 \mathrm{mU}$. $\left.\mathrm{kg}^{-1} \cdot \mathrm{min}^{-1}\right)$ in awake animals. C-peptide infusion rates were 0.05 and $0.5 \mathrm{nmol} \cdot \mathrm{kg}^{-1} \cdot \mathrm{min}^{-1}$. Blood glucose was clamped at $7.7 \pm 0.3 \mathrm{mmol} / \mathrm{l}$ in the diabetic rats and at $3.9 \pm 0.1 \mathrm{mmol} / \mathrm{l}$ in the healthy rats.

Results. In diabetic rats infused at lower rates of C peptide and insulin, glucose utilization increased by $79-90 \%(p<0.001)$ compared with diabetic animals infused with saline and insulin. Increasing the rate of C-peptide infusion tenfold did not elicit a statistically significant further increase in glucose utilization. C peptide I and II exerted similar effects. The metabolic clearance rate for glucose in the diabetic animals infused with $\mathrm{C}$ peptide was not different from that of the healthy rats. During high-dose insulin infusion $\left(30.0 \mathrm{mU} \cdot \mathrm{kg}^{-1} \cdot \mathrm{min}^{-1}\right)$ glucose utilization increased considerably and no statistically significant $\mathrm{C}$-peptide effects were observed. About $85 \%$ of the increase in glucose utilization induced by $\mathrm{C}$ peptide could be blocked by treatment with $N$-monomethyl-L-arginine. Conclusions/interpretation. Physiological concentrations of homologous $\mathrm{C}$ peptide stimulate whole body glucose utilization in diabetic but not in healthy rats. $\mathrm{C}$ peptide I and II elicit similar effects. The influence of $C$ peptide on glucose utilization may be mediated by nitric oxide. [Diabetologia (1999) 42: 958-964]

Keywords Insulin action, diabetes mellitus, euglycaemic clamp, C peptide, nitric oxide.
The C peptide of proinsulin has since its discovery been considered to be without biological effect of its own [1]. In recent years it has been reported, however, that $\mathrm{C}$ peptide increases muscle blood flow, glucose and oxygen uptake of the exercising forearm, decreases urinary albumin excretion and improves autonomic nerve function in patients with Type I (in-

Received: 8 January 1999 and in final revised form: 20 April 1999

Corresponding author: Y. Sato, MD, PhD, Research Centre of Health, Physical Fitness and Sports, Nagoya University, Furocho, chikusa-ku, Nagoya 464-8601, Japan

Abbreviations: STZ, Streptozotocin; GDR, glucose disposal rate; $\mathrm{MCR}$, metabolic clearance rate for glucose; $\mathrm{NO}$, nitric oxide; L-NMMA, $N$-monomethyl-L-arginine. sulin-dependent) diabetes mellitus [2-6]. Moreover, $\mathrm{C}$ peptide has been shown to stimulate $\mathrm{Na}^{+}, \mathrm{K}^{+}$-ATPase activity in renal tubular cells [7] and to activate the nitric oxide (NO) synthase of endothelial cells [8]. The rat has two proinsulins and thus two C peptides that differ with regard to two amino acids in the middle segment of the molecule [9]. Rat C peptide I and II are equipotent in their ability to stimulate $\mathrm{Na}^{+}, \mathrm{K}^{+}$-ATPase [7]. Studies on isolated muscle strips from Type I diabetic patients and healthy subjects have confirmed the effect of $\mathrm{C}$ peptide on glucose transport in vivo and indicated that the stimulation occurs through pathways that do not include the insulin receptor [10]. C peptide does not, however, stimulate muscle glycogen synthesis in isolated mouse muscle [11]. Recent data show that glucose transport in rat muscle and adipose tissue can be 
stimulated by NO through a pathway that is different from both the insulin-dependent and the contractionactivated mechanisms $[12,13]$. Our aim was to determine whether physiological plasma concentrations of homologous $\mathrm{C}$ peptide increase whole body glucose utilization using the euglycaemic clamp technique in streptozotocin (STZ)-induced diabetic and healthy rats in the awake condition and to examine, on a preliminary basis, if such an effect is diminished by treatment with an NO synthase inhibitor.

\section{Animals and methods}

Animals. Male Wistar rats $(n=83)$ weighing between $190-230$ $\mathrm{g}$ were used for the study. Animals were housed in individual cages in a room maintained at $23^{\circ} \mathrm{C}$ with an alternating $12-\mathrm{h}$ light/dark cycle, where they had free access to standard diet and water. The rats were anaesthetized with an i.p. injection of $50 \mathrm{mg} / \mathrm{kg}$ sodium pentobarbital. The right jugular vein and the left carotid artery were then exposed and isolated through a middle neck incision. Thin silasitic catheters were introduced and secured with a silk ligature. The free ends of the catheters were attached to the short segments of steel tubing and tunnelled subcutaneously around the side of the neck to the top of the skull where they were threaded through a skin incision to the exterior. After patency was checked, the catheters were flushed with $300 \mu \mathrm{l}$ of $0.9 \% \mathrm{NaCl}$ solution containing heparin (40 U/ml) and then $500 \mu 1$ sodium penicillin $\mathrm{G}(10,000 \mathrm{U} / \mathrm{ml})$ was injected. After penicillin injection, STZ $(55 \mathrm{mg} / \mathrm{kg}$ body weight, Sigma, St. Louis, Mo., USA) was injected i.v. for the diabetic rats and citrate buffer was given for the control rats. The catheters were then filled with a viscous solution of $50 \%$ polyvinypyrrollidon (PVP K-30, Nacalai, Tesque, Kyoto, Japan) and capped. The rats were then allowed to resume normal behaviour. Animal care conformed with the standards set by the "Principles of Laboratory care" (NIH publication no. 85-23, revised 1985) and the "Guidelines for animal experimentation" (Nagoya University 1988).

Euglycaemic insulin clamp technique. The animals were allowed to recover from surgery for at least 5 days. The clamp studies were then done in the morning after a 16-h overnight fast. Throughout the study, the rats were allowed to move freely within a large cage. The PVP solution was aspirated from the catheter, and the venous catheter was then used for the infusions of glucose $(20 \%)$, insulin (Actrapid MC, Novo Nordisk, Bagsvaerd, Denmark), C peptide or saline by infusion pumps (STC-521, Terumo, Tokyo, Japan). The rat C peptide I or II (infusion rate: 0.05 or $0.5 \mathrm{nmol} \cdot \mathrm{kg}^{-1} \cdot \mathrm{min}^{-1}$ ) had a purity greater than $99 \%$ by HPLC (Genosys, Cambridge, UK). Saline was given instead of $\mathrm{C}$ peptide in the control study. The blood samples for glucose $(25 \mu 1$ per sample) and hormone $(0.5 \mathrm{ml})$ determinations were drawn from the arterial cannula. The total blood loss during the experimental procedure did not exceed $1.5 \mathrm{ml}$. In the diabetic rats the blood glucose concentrations were lowered to $7.8 \mathrm{mmol} / 1$ and then clamped at this concentration with periodic adjustment of the glucose infusion rate. In the clamp studies, the insulin infusions were given at rates of 3.0 (low-dose, 0-90 min) and then 30.0 (highdose, 90-180 $\mathrm{min}) \mathrm{mU} \cdot \mathrm{kg}^{-1} \cdot \mathrm{min}^{-1}$. During the euglycaemic clamp, blood glucose concentrations were measured every $10 \mathrm{~min}$ and the euglycaemia of diabetic and normal rats was maintained at around $7.7 \pm 0.3 \mathrm{mmol} / \mathrm{l}$ and $3.9 \pm 0.1 \mathrm{mmol} / \mathrm{l}$, respectively. All of the infused glucose was considered to be tak- en up by body tissues and under these steady-state conditions of euglycaemia and hyperinsulinaemia, glucose input is equal to glucose utilization. The glucose disposal rate (GDR) in $\mu \mathrm{mol} \cdot \mathrm{kg}^{-1} \cdot \mathrm{min}^{-1}$ was calculated every $10 \mathrm{~min}$ during the clamp study. Metabolic clearance rate for glucose (MCR, $\mathrm{ml} \cdot \mathrm{kg}^{-1} \cdot \mathrm{min}^{-1}$ ) was then obtained from GDR divided by the corresponding blood glucose concentration. The GDR and the MCR from 60 to 90 min for the euglycaemic clamp procedure were regarded as indices of insulin action in peripheral tissues, since a plateau glucose infusion rate was achieved during this time, as reported previously $[14,15]$. In a final group of rats $N$-monomethyl-L-arginine (L-NMMA, Calbiochem-Novabiochem, Nottingham, England) was infused $\left(1 \mathrm{mg} \cdot \mathrm{kg}^{-1} \cdot \mathrm{min}^{-1}\right)$ in diabetic rats together with $\mathrm{C}$ peptide I $\left(0.05 \mathrm{nmol} \cdot \mathrm{kg}^{-1} \cdot \mathrm{min}^{-1}\right)$ during low-dose insulin infusion according to the same protocol as described above. In addition, an infusion of adenosine $\left(1.5 \mu \mathrm{mol} \cdot \mathrm{kg}^{-1} \cdot \mathrm{min}^{-1}\right.$, Sigma) was given together with L-NMMA and $\mathrm{C}$ peptide in a subgroup of animals. The dosage for L-NMMA and adenosine were expected to be sufficient to effect NO-synthase inhibition [16] and elicit vasodilatory effects [17].

Analytical methods. Blood glucose concentrations were determined with a YSI 23 A glucose analyser (Yellow Spring Instrument, Yellow Springs, Ohio, USA). The samples for plasma insulin and C-peptide determination $(0.5 \mathrm{ml})$ were obtained just before insulin and C-peptide infusion and immediately at the end of the low-dose and the high-dose insulin clamps, respectively. Plasma insulin concentrations were determined by radioimmunological technique (Phadeseph Insulin RIA, Pharmacia AB, Uppsala, Sweden). Plasma C-peptide concentrations were assayed using an enzyme-linked immunosorbent assay (ELISA) [18]. In the assay the first tracer was biotinylized rat $\mathrm{C}$ peptide and the second tracer was streptavidin labelled by horseradish peroxidase by Yanaihara Institute, Shizuoka, Japan. The measurements were done with a homologous antibody.

Statistical analyses. All values were expressed as means \pm SEM. The concentrations of plasma glucose, insulin and $\mathrm{C}$ peptide and the GDR and the MCR were compared between normal and diabetic rats with unpaired Student's $t$ test. A one-way analysis of variance (ANOVA) was used to evaluate the differences in GDRs and MCRs in the presence or absence of $\mathrm{C}$ peptide and in concentrations of $\mathrm{C}$ peptide before and after C-peptide infusion in the clamp procedure. When significance was established, the difference between individual groups of data was tested for significance using a Fisher's PLSD test. $P$ values less than 0.05 were considered significant.

\section{Results}

Body weight, blood glucose, plasma insulin and Cpeptide concentrations. Body weight, blood glucose and plasma insulin concentrations before and after the clamp procedure are shown in Table 1. Basal blood glucose concentrations were significantly higher in the diabetic rats compared with the normal controls but the basal plasma insulin concentrations of the diabetic rats showed a considerable decrease, as expected. During the clamp studies, the glucose concentrations in the diabetic rats were maintained at $7.7-7.8 \mathrm{mmol} / \mathrm{l}$ and those in the normal rats were kept at the basal concentrations. During the low- 
Table 1. Body weight and concentrations of blood glucose and plasma insulin before and immediately after the euglycaemic clamp procedure at the low-dose $\left(3.0 \mathrm{mU} \cdot \mathrm{kg}^{-1} \cdot \mathrm{min}^{-1}\right)$ and the high-dose $\left(30.0 \mathrm{mU} \cdot \mathrm{kg}^{-1} \cdot \mathrm{min}^{-1}\right)$ insulin infusion

\begin{tabular}{|c|c|c|c|c|c|c|c|c|}
\hline & & \multirow[t]{2}{*}{ Body wt (g) } & \multicolumn{3}{|c|}{ Glucose (mmol/l) } & \multicolumn{3}{|c|}{ Insulin (pmol/1) } \\
\hline & & & $0 \mathrm{~min}$ & $\begin{array}{l}\text { Low-dose } \\
90 \mathrm{~min}\end{array}$ & $\begin{array}{l}\text { High-dose } \\
180 \mathrm{~min}\end{array}$ & $0 \mathrm{~min}$ & $\begin{array}{l}\text { Low-dose } \\
90 \mathrm{~min}\end{array}$ & $\begin{array}{l}\text { High-dose } \\
180 \mathrm{~min}\end{array}$ \\
\hline $\begin{array}{l}0.05 \mathrm{nmol} \cdot \mathrm{kg}^{-1} \\
\mathrm{~min}^{-1} \text { of C-peptide } \\
\text { infusion }\end{array}$ & $\begin{array}{l}\text { Healthy } \\
\text { Saline (8) } \\
\text { C peptide I (8) } \\
\text { C peptide II (8) }\end{array}$ & $\begin{array}{l}214 \pm 6 \\
226 \pm 9 \\
225 \pm 5\end{array}$ & $\begin{array}{l}3.9 \pm 0.1 \\
4.0 \pm 0.1 \\
4.1 \pm 0.1\end{array}$ & $\begin{array}{l}3.7 \pm 0.2 \\
4.0 \pm 0.1 \\
4.0 \pm 0.1\end{array}$ & $\begin{array}{l}3.4 \pm 0.1 \\
3.7 \pm 0.2 \\
3.9 \pm 0.1\end{array}$ & $\begin{array}{r}106 \pm 21 \\
99 \pm 20 \\
99 \pm 14\end{array}$ & $\begin{array}{l}241 \pm 14 \\
220 \pm 28 \\
248 \pm 27\end{array}$ & $\begin{array}{l}2939 \pm 319 \\
2669 \pm 312 \\
3017 \pm 390\end{array}$ \\
\hline $\begin{array}{l}0.5 \mathrm{nmol} \cdot \mathrm{kg}^{-1} \\
\text { min }^{-1} \text { of C-peptide } \\
\text { infusion }\end{array}$ & $\begin{array}{l}\text { Healthy } \\
\text { C peptide I (5) } \\
\text { C peptide II (5) }\end{array}$ & $\begin{array}{l}230 \pm 4 \\
227 \pm 5\end{array}$ & $\begin{array}{l}3.9 \pm 0.1 \\
3.7 \pm 0.2\end{array}$ & $\begin{array}{l}4.0 \pm 0.2 \\
3.9 \pm 0.2\end{array}$ & $\begin{array}{l}3.4 \pm 0.1 \\
3.4 \pm 0.1\end{array}$ & $\begin{array}{l}85 \pm 21 \\
78 \pm 7\end{array}$ & $\begin{array}{l}255 \pm 14 \\
256 \pm 14\end{array}$ & $\begin{array}{l}3045 \pm 483 \\
3124 \pm 631\end{array}$ \\
\hline & $\begin{array}{l}\text { Diabetic } \\
\text { C peptide I (5) } \\
\text { C peptide II (5) }\end{array}$ & $\begin{array}{l}209 \pm 4 \\
211 \pm 5\end{array}$ & $\begin{array}{l}12.1 \pm 0.9^{\mathrm{b}} \\
12.5 \pm 0.7^{\mathrm{b}}\end{array}$ & $\begin{array}{l}7.7 \pm 0.2 \\
7.8 \pm 0.3\end{array}$ & $\begin{array}{l}7.4 \pm 0.5 \\
7.6 \pm 0.3\end{array}$ & $\begin{array}{l}43 \pm 7^{\mathrm{a}} \\
50 \pm 7^{\mathrm{a}}\end{array}$ & $\begin{array}{l}213 \pm 36 \\
234 \pm 42\end{array}$ & $\begin{array}{l}2825 \pm 440 \\
2889 \pm 376\end{array}$ \\
\hline
\end{tabular}

Values are means \pm SEM. The number of rats is shown in parentheses. ${ }^{\mathrm{a}}$ Indicates a $p<0.05$ vs healthy, ${ }^{\mathrm{b}}$ indicates a $p<0.001$ vs healthy. $t$, time points as measured from blood

Table 2. C-peptide concentrations before and immediately after the euglycaemic clamp procedure at the low-dose (0-90 min; $\left.3.0 \mathrm{mU} \cdot \mathrm{kg}^{-1} \cdot \mathrm{min}^{-1}\right)$ and the high-dose $\left(90-180 \mathrm{~min} ; 30.0 \mathrm{mU} \cdot \mathrm{kg}^{-1} \cdot \mathrm{min}^{-1}\right)$ insulin infusion

\begin{tabular}{|c|c|c|c|c|}
\hline & & \multicolumn{3}{|c|}{ C peptide (nmol/l) } \\
\hline & & $0 \mathrm{~min}$ & Low-dose clamp 90 min & High-dose clamp $180 \mathrm{~min}$ \\
\hline \multirow[t]{2}{*}{$\begin{array}{l}0.05 \mathrm{nmol} \cdot \mathrm{kg}^{-1} \cdot \mathrm{min}^{-1} \\
\text { of C-peptide infusion }\end{array}$} & $\begin{array}{l}\text { Healthy } \\
\text { Saline (8) } \\
\text { C peptide I (8) } \\
\text { C peptide II (8) }\end{array}$ & $\begin{array}{l}1.48 \pm 0.3 \\
1.07 \pm 0.3 \\
1.45 \pm 0.3\end{array}$ & $\begin{array}{l}1.05 \pm 0.2 \\
4.91 \pm 1.1^{\mathrm{b}} \\
5.07 \pm 1.6^{\mathrm{b}}\end{array}$ & $\begin{array}{l}1.72 \pm 0.2 \\
7.30 \pm 0.3^{\mathrm{b}} \\
6.49 \pm 1.7^{\mathrm{b}}\end{array}$ \\
\hline & $\begin{array}{l}\text { Diabetic } \\
\text { Saline (8) } \\
\text { C peptide I (8) } \\
\text { C peptide II (8) }\end{array}$ & $\begin{array}{l}0.21 \pm 0.1^{\mathrm{a}} \\
0.05 \pm 0.01^{\mathrm{a}} \\
0.05 \pm 0.02^{\mathrm{a}}\end{array}$ & $\begin{array}{l}0.09 \pm 0.03 \\
3.45 \pm 0.9^{b} \\
2.85 \pm 0.8^{b}\end{array}$ & $\begin{array}{l}0.22 \pm 0.03 \\
3.77 \pm 1.5^{\mathrm{b}} \\
3.25 \pm 0.8^{\mathrm{b}}\end{array}$ \\
\hline \multirow[t]{2}{*}{$\begin{array}{l}0.5 \mathrm{nmol} \cdot \mathrm{kg}^{-1} \cdot \mathrm{min}^{-1} \\
\text { of C-peptide infusion }\end{array}$} & $\begin{array}{l}\text { Healthy } \\
\text { C peptide I (5) } \\
\text { C peptide II (5) }\end{array}$ & $\begin{array}{l}1.73 \pm 0.5 \\
1.43 \pm 0.6\end{array}$ & $\begin{array}{l}26.0 \pm 4.9^{\mathrm{c}} \\
25.1 \pm 11.1^{\mathrm{c}}\end{array}$ & $\begin{array}{l}52.5 \pm 5.0^{c} \\
48.3 \pm 10.0^{c}\end{array}$ \\
\hline & $\begin{array}{l}\text { Diabetic } \\
\text { C peptide I (5) } \\
\text { C peptide II (5) }\end{array}$ & $\begin{array}{l}0.03 \pm 0.01^{\mathrm{a}} \\
0.03 \pm 0.01^{\mathrm{a}}\end{array}$ & $\begin{array}{l}25.3 \pm 4.7^{\mathrm{c}} \\
27.5 \pm 3.5^{\mathrm{c}}\end{array}$ & $\begin{array}{l}46.4 \pm 9.1^{\mathrm{c}} \\
51.7 \pm 7.4^{\mathrm{c}}\end{array}$ \\
\hline
\end{tabular}

Values are means \pm SEM. The number of rats is shown in parentheses. ${ }^{\text {a }}$ Indicates a $p<0.01$ vs healthy, ${ }^{\text {b }}$ indicates a $p<0.01$ vs $0 \mathrm{~min},{ }^{\mathrm{c}}$ indicates $p=0.001 \mathrm{vs} 0 \mathrm{~min}$. $\mathrm{t}$, time points as measured from blood

dose and the high-dose insulin clamp procedure, steady state plasma insulin concentrations were not significantly different between the diabetic and the normal rats. The basal C-peptide concentrations of the diabetic rats were significantly lower than those of the normal rats (Table 2). During C-peptide infusion $\left(0.05 \mathrm{nmol} \cdot \mathrm{kg}^{-1} \cdot \mathrm{min}^{-1}\right)$ in the diabetic rats, the concentration of the peptide increased to $2.8-3.7 \mathrm{nmol} / 1$ with similar concentrations being reached with infusion of C peptide I and II. Similar conditions were obtained during C-peptide infusion into normal rats except that C-peptide concentrations continued to increase during the high-dose glucose clamp, reaching concentrations of approximately $6-7 \mathrm{nmol} / \mathrm{l}$ (Ta- ble 2). C peptide I and II infusion at $0.5 \mathrm{nmol}$. $\mathrm{kg}^{-1} \cdot \mathrm{min}^{-1}$ resulted in concentrations of approximately $50 \mathrm{nmol} / \mathrm{l}$ with similar concentrations for $\mathrm{C}$ peptide I and II.

Glucose disposal rate. The average GDRs for the last 30 min during the low-dose and the high-dose insulin infusion rates are shown in Table 3. Because a plateau glucose infusion rate was achieved (Figs. 1,2) GDR was used as an indicator of the whole-body glucose utilization. At the insulin infusion rate of $3.0 \mathrm{mU}$. $\mathrm{kg}^{-1} \cdot \mathrm{min}^{-1}$ in the diabetic rats, the dosage of 0.05 $\mathrm{nmol} \cdot \mathrm{kg}^{-1} \cdot \mathrm{min}^{-1}$ of C peptide I and II resulted in similar and pronounced increases in GDRs (C peptide I: 
Table 3. Glucose disposal rate (GDR) for the last $30 \mathrm{~min}$ during the eulycaemic clamp procedure at the low-dose (0-90 min, $\left.3.0 \mathrm{mU} \cdot \mathrm{kg}^{-1} \cdot \mathrm{min}^{-1}\right)$ and the high-dose $\left(90-180 \mathrm{~min}, 30.0 \mathrm{mU} \cdot \mathrm{kg}^{-1} \cdot \mathrm{min}^{-1}\right)$ insulin infusion

\begin{tabular}{|c|c|c|c|}
\hline & & \multicolumn{2}{|l|}{ GDRs $\left(\mu \mathrm{mol} \cdot \mathrm{kg}^{-1} \cdot \mathrm{min}^{-1}\right)$} \\
\hline & & Low-dose insulin infusion & High-dose insulin infusion \\
\hline \multirow[t]{2}{*}{$0.05 \mathrm{nmol} \cdot \mathrm{kg}^{-1} \cdot \mathrm{min}^{-1}$ of C-peptide infusion } & $\begin{array}{l}\text { Healthy } \\
\text { Saline (8) } \\
\text { C peptide I ( } 8) \\
\text { C peptide II (8) }\end{array}$ & $\begin{array}{l}71.1 \pm 9.4 \\
72.2 \pm 10.0 \\
71.1 \pm 6.6\end{array}$ & $\begin{array}{l}222.2 \pm 16.6 \\
241.1 \pm 6.7 \\
236.1 \pm 8.9\end{array}$ \\
\hline & $\begin{array}{l}\text { Diabetic } \\
\text { Saline (8) } \\
\text { C peptide I ( } 8) \\
\text { C peptide II (8) }\end{array}$ & $\begin{array}{c}61.7 \pm 6.1 \\
118.3 \pm 11.1^{\mathrm{a}} \\
111.1 \pm 9.4^{\mathrm{a}}\end{array}$ & $\begin{array}{l}263.3 \pm 20.5 \\
293.9 \pm 21.7 \\
271.7 \pm 19.4\end{array}$ \\
\hline \multirow[t]{2}{*}{$0.5 \mathrm{nmol} \cdot \mathrm{kg}^{-1} \cdot \mathrm{min}^{-1}$ of C-peptide infusion } & $\begin{array}{l}\text { Healthy } \\
\text { C peptide I (5) } \\
\text { C peptide II (5) }\end{array}$ & $\begin{array}{l}70.1 \pm 8.7 \\
68.7 \pm 7.5\end{array}$ & $\begin{array}{l}235.2 \pm 10.4 \\
242.7 \pm 13.4\end{array}$ \\
\hline & $\begin{array}{l}\text { Diabetic } \\
\text { C peptide I (5) } \\
\text { C peptide II (5) }\end{array}$ & $\begin{array}{l}144.1 \pm 26.6^{\mathrm{a}} \\
136.0 \pm 7.8^{\mathrm{a}}\end{array}$ & $\begin{array}{l}316.7 \pm 22.3 \\
314.4 \pm 24.1\end{array}$ \\
\hline
\end{tabular}

Values are means \pm SEM. The number of rats is shown in parentheses. ${ }^{\text {a }}$ Indicates a $p<0.001$ vs diabetic rats given saline

$118 \pm 11 \mu \mathrm{mol} \cdot \mathrm{kg}^{-1} \cdot \mathrm{min}^{-1} ; \quad \mathrm{C}$ peptide $\mathrm{II}: 111 \pm$ $\left.9 \mu \mathrm{mol} \cdot \mathrm{kg}^{-1} \cdot \mathrm{min}^{-1}\right)$ compared with diabetic rats infused with saline $\left(62 \pm 6 \mu \mathrm{mol} \cdot \mathrm{kg}^{-1} \cdot \mathrm{min}^{-1}, p<0.001\right)$ (Fig. 1). The infusion of $0.5 \mathrm{nmol} \cdot \mathrm{kg}^{-1} \cdot \mathrm{min}^{-1}$ of C pep-

Fig. 1A, B. Glucose disposal rates (GDRs) for the euglycaemic clamp procedure at the low-dose $\left(3.0 \mathrm{mU} \cdot \mathrm{kg}^{-1} \cdot \mathrm{min}^{-1}\right)$ and the high-dose $\left(30.0 \mathrm{mU} \cdot \mathrm{kg}^{-1} \cdot \mathrm{min}^{-1}\right)$ insulin infusion during the treatment with $0.05 \mathrm{nmol} \cdot \mathrm{kg}^{-1} \cdot \mathrm{min}^{-1} \mathrm{C}$ peptide I or II or Saline. A Healthy rats, B diabetic rats. ( $\bigcirc)$ saline infusion; (O) C peptide I infusion; ( $\square$ C peptide II infusion. Values are means \pm SEM tide I and II also stimulated significant increases in GDRs (C peptide I: $144 \pm 27 \mu \mathrm{mol} \cdot \mathrm{kg}^{-1} \cdot \mathrm{min}^{-1}$, and C peptide II: $136 \pm 8 \mu \mathrm{mol} \cdot \mathrm{kg}^{-1} \cdot \min ^{-1}$, respectively) compared with rats infused with saline $(p<0.001)$, the increments being similar to those observed during $0.05 \mathrm{nmol} \cdot \mathrm{kg}^{-1} \cdot \mathrm{min}^{-1}$ infusion of $\mathrm{C}$ peptide I or II (Fig. 2). In the high-dose insulin clamp studies, infusion of 0.05 or $0.5 \mathrm{nmol} \cdot \mathrm{kg}^{-1} \cdot \mathrm{min}^{-1}$ of C peptide I and II tended to increase the GDRs but not significantly so (Table 3). In the normal rats, infusion of 0.05 or $0.5 \mathrm{nmol} \cdot \mathrm{kg}^{-1} \cdot \mathrm{min}^{-1} \mathrm{C}$ peptide I or II did not increase GDRs either during the low-dose or the high-dose insulin clamp studies (Table 3 ).

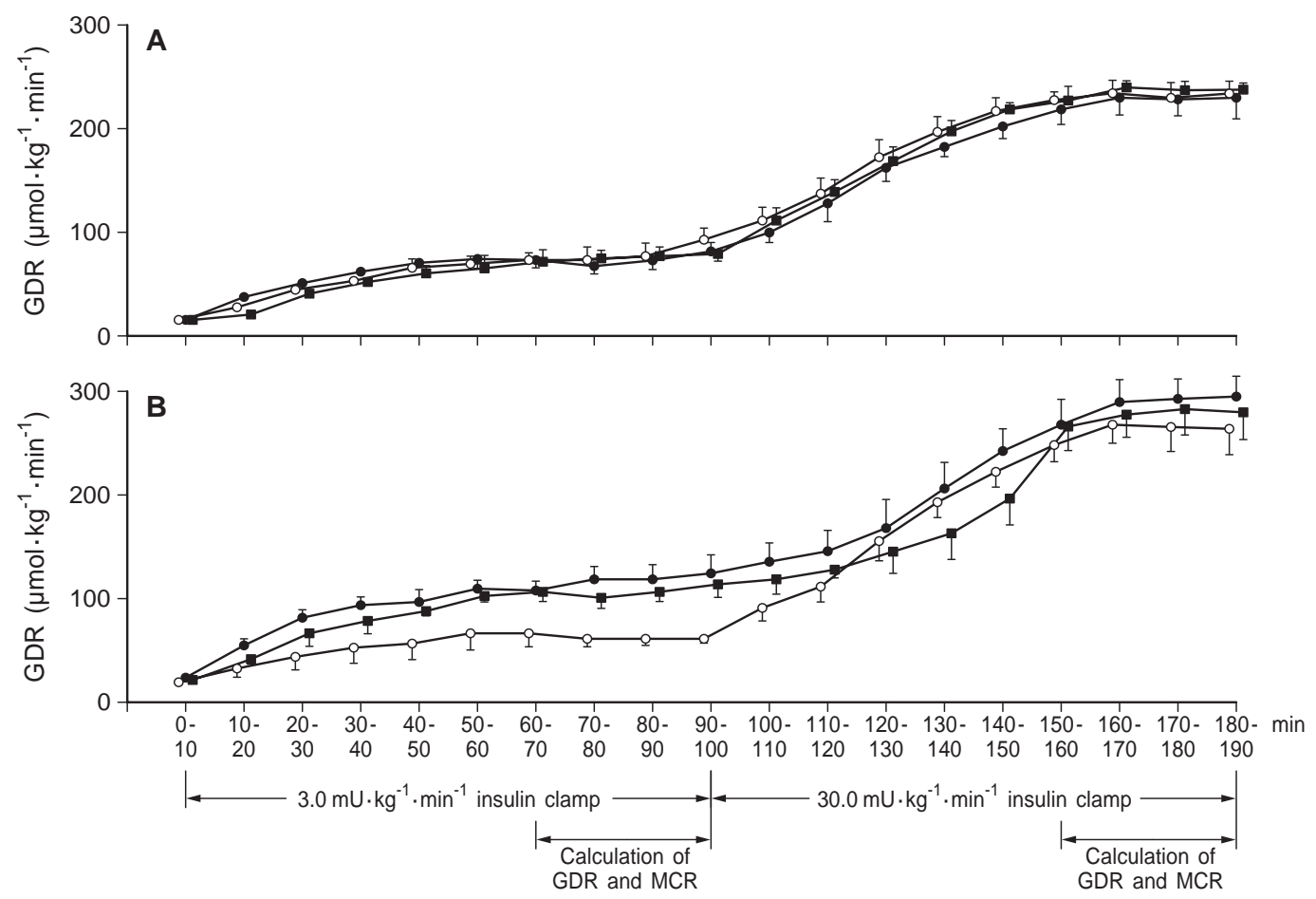




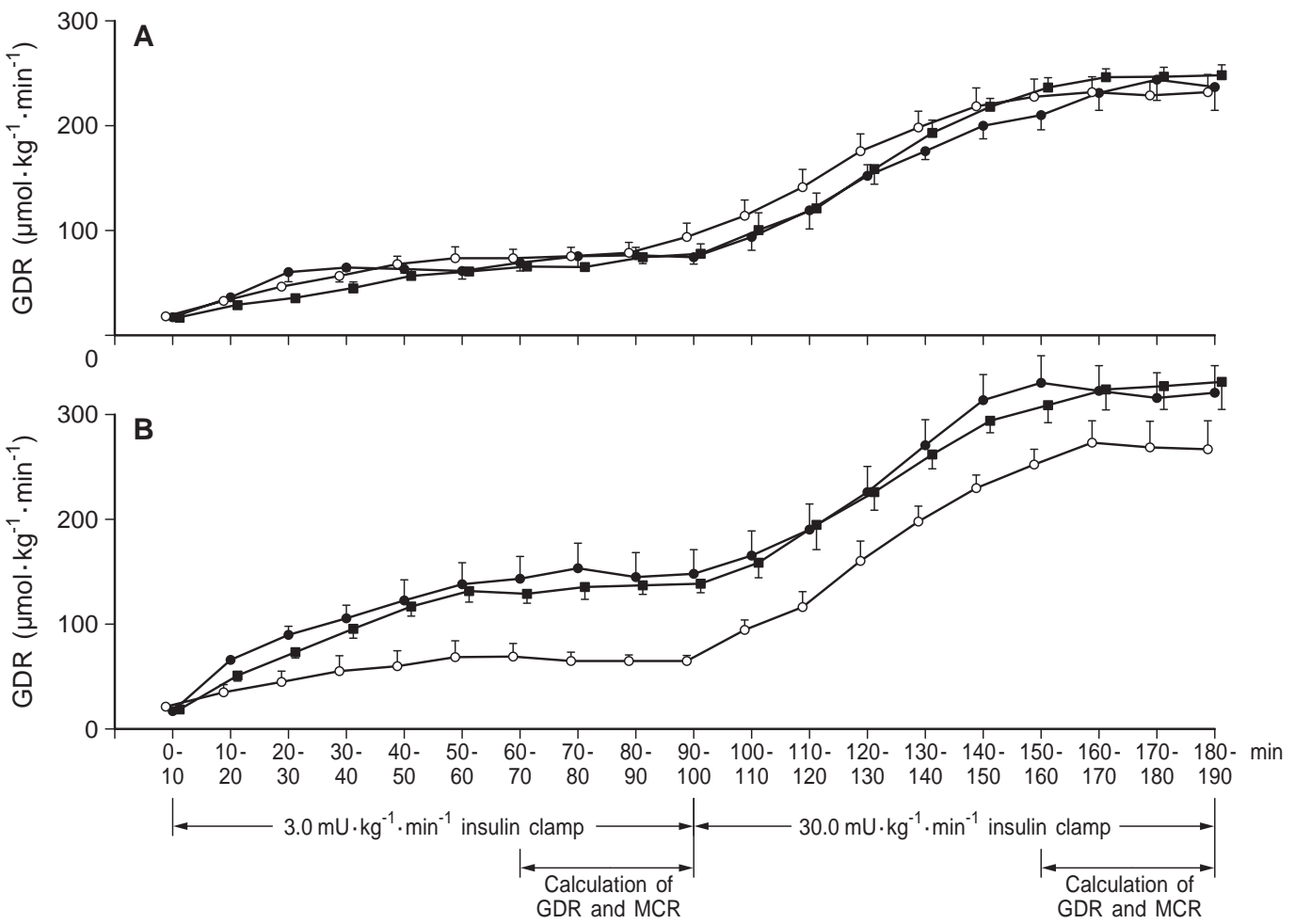

Fig. 2 A, B. Glucose disposal rates (GDRs) for the euglycaemic clamp procedure at the low-dose $\left(3.0 \mathrm{mU} \cdot \mathrm{kg}^{-1} \cdot \mathrm{min}^{-1}\right)$ and the high-dose $\left(30.0 \mathrm{mU} \cdot \mathrm{kg}^{-1} \cdot \mathrm{min}^{-1}\right)$ insulin infusion during the treatment with $0.5 \mathrm{nmol} \cdot \mathrm{kg}^{-1} \cdot \mathrm{min}^{-1} \mathrm{C}$ peptide I or II or saline. A healthy rats, $\mathbf{B}$ diabetic rats. ( $\bigcirc)$ Saline infusion; (O) C peptide I infusion; ( $\square$ C peptide II infusion. Values are means $\pm \mathrm{SEM}$

Metabolic clearance rate for glucose. In the low-dose insulin clamp studies, the diabetic rats treated with the infusions of $0.05 \mathrm{nmol} \cdot \mathrm{kg}^{-1} \cdot \mathrm{min}^{-1}$ of C peptide I and II showed significantly higher MCRs (C peptide I: $18.0 \pm 2.8 \mathrm{ml} \cdot \mathrm{kg}^{-1} \cdot \mathrm{min}^{-1} ; \mathrm{C}$ peptide II: $16.1 \pm$ $\left.2.1 \mathrm{ml} \cdot \mathrm{kg}^{-1} \cdot \mathrm{min}^{-1}\right)$ than those of the diabetic rats given saline $\left(8.0 \pm 0.8 \mathrm{ml} \cdot \mathrm{kg}^{-1} \cdot \mathrm{min}^{-1}, p<0.001\right)$. Likewise, animals treated with infusions of $0.5 \mathrm{nmol}$. $\mathrm{kg}^{-1} \cdot \mathrm{min}^{-1}$ of $\mathrm{C}$ peptide I and II also showed significant increase in MCRs but of a similar magnitude as during the $0.05 \mathrm{nmol} \cdot \mathrm{kg}^{-1} \cdot \mathrm{min}^{-1} \mathrm{C}$-peptide infusions (Table 4). In the low-dose insulin infusions, the MCRs of the diabetic rats, which were stimulated by $\mathrm{C}$ peptide I or II, reached similar concentrations as the healthy rats. No effects of C-peptide treatment were seen on MCRs in healthy rats during the low-dose or the high-dose insulin clamp studies (Table 4).

$N$-monomethyl-L-arginine. Studies involving simultaneous infusion of L-NMMA and $\mathrm{C}$ peptide showed that approximately $85 \%$ of the increase induced by $\mathrm{C}$ peptide in GDR during low-dose insulin treatment could be blocked by L-NMMA (Fig. 3). In an attempt to overcome possible circulation-related reductions in GDR, adenosine was co-infused with $\mathrm{C}$ peptide and L-NMMA, but this did not result in a change in GDR beyond the findings for L-NMMA and C peptide alone (Fig. 3).

\section{Discussion}

The primary finding of our study is that physiological concentrations of homologous rat $\mathrm{C}$ peptide I or II have the capacity to greatly augment whole-body glucose disposal and MCR for glucose in STZ-diabetic rats. The animals were $C$ peptide negative at the outset of the study (Table 2) and during infusion of the C peptide the concentrations increased to $2.8-3.5 \mathrm{nmol} / \mathrm{l}$, values within the physiological range. This increase in concentration of $\mathrm{C}$ peptide was accompanied by an $80-90 \%$ increase in GDR and a $100-125 \%$ increase in MCR (Tables 3, 4). In contrast, no effects on either GDR or MCR could be seen in healthy rats. When the C-peptide infusion rate was increased and higher C-peptide concentrations were reached, no further effects were seen in the diabetic rats.

The effect observed on whole-body glucose utilization is most likely a consequence of direct stimulation by $\mathrm{C}$ peptide of muscle glucose utilization. This is supported by the previously observed in vivo stimulation of forearm muscle glucose uptake by $\mathrm{C}$ peptide in Type 1 diabetic patients both at the rest and during exercise $[3,19]$. In addition, measurements in vitro of glucose uptake stimulated by $\mathrm{C}$ peptide by muscle from healthy subjects and from patients with Type I diabetes indicate a direct stimulatory effect through 
Table 4. Metabolic clearance rate (MCR) for glucose for the last 30 min during the euglycaemic clamp procedure at the low-dose (0-90 $\left.\mathrm{min}, 3.0 \mathrm{mU} \cdot \mathrm{kg}^{-1} \cdot \mathrm{min}^{-1}\right)$ and the high-dose $\left(90-180 \mathrm{~min}, 30.0 \mathrm{mU} \cdot \mathrm{kg}^{-1} \cdot \mathrm{min}^{-1}\right)$ insulin infusion

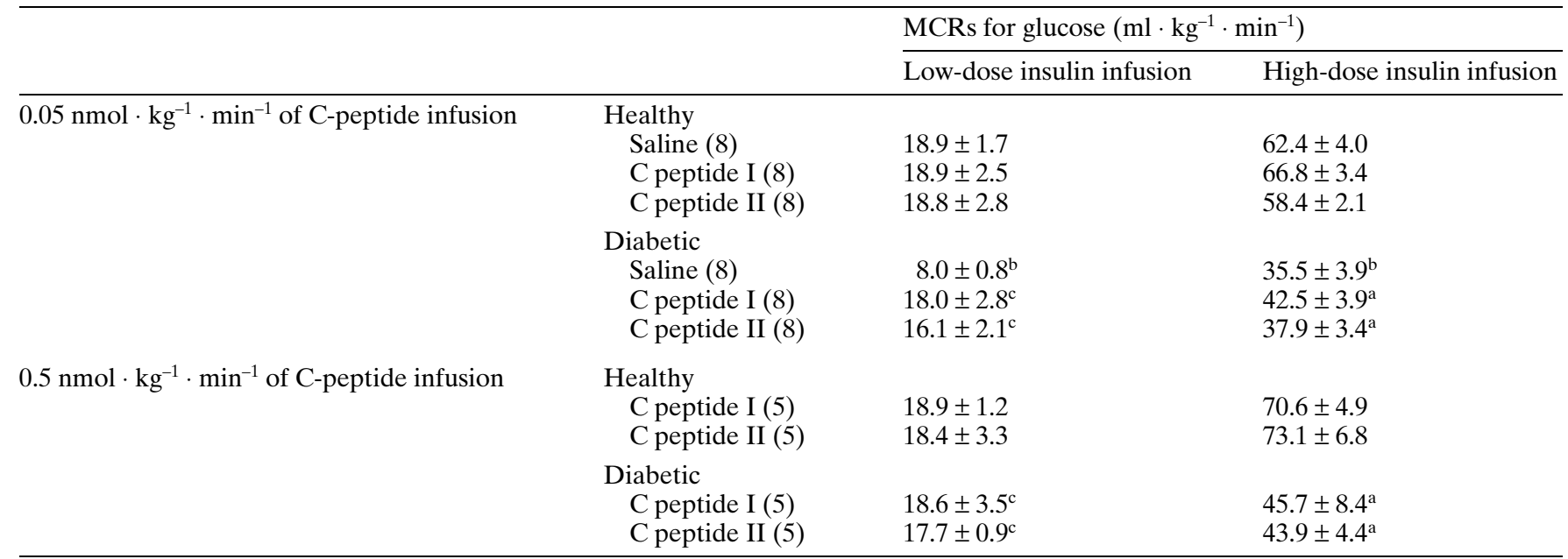

Values are means \pm SEM. The number of rats is shown in parentheses. ${ }^{\mathrm{a}}$ Indicates a $p<0.05$ vs healthy rats given saline. ${ }^{\mathrm{b}}$ Indicates a $p<0.001$ vs healthy rats given saline. ${ }^{\mathrm{c}}$ Indicates a $p<0.001$ vs diabetic rats given saline

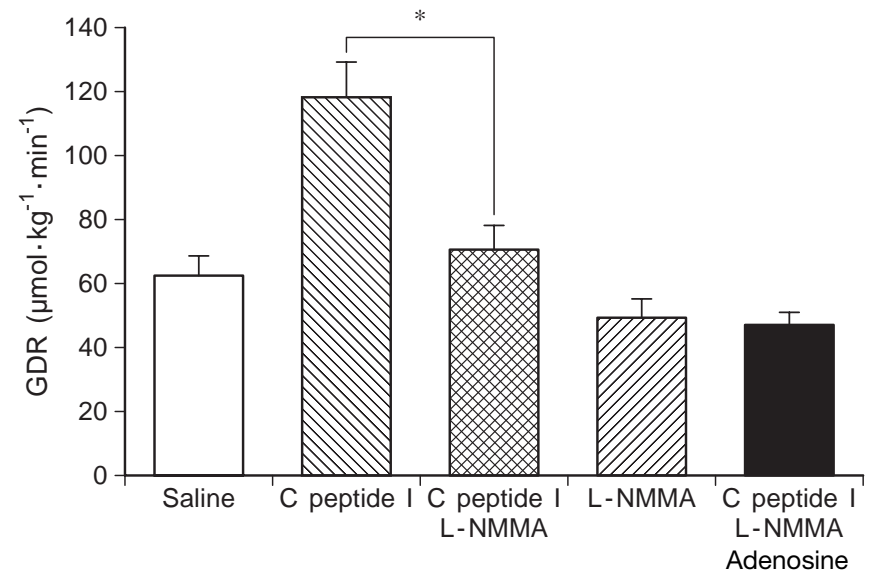

Fig.3. Glucose disposal rates (GDRs) during the euglycaemic clamp procedure in diabetic rats at the low-dose $(3.0 \mathrm{mU}$. $\left.\mathrm{kg}^{-1} \cdot \mathrm{min}^{-1}\right)$ insulin infusion during infusion of saline $(n=8)$, C peptide I $\left(0.05 \mathrm{nmol} \cdot \mathrm{kg}^{-1} \cdot \mathrm{min}^{-1}, n=8\right)$, C peptide $\mathrm{I}+\mathrm{L}-$ NMMA $\left(1 \mathrm{mg} \cdot \mathrm{kg}^{-1} \cdot \mathrm{min}^{-1}, n=5\right)$, L-NMMA only $(n=5)$ or $\mathrm{C}$ peptide $+\mathrm{L}-\mathrm{NMMA}+$ adenosine $\left(1.5 \mu \mathrm{mol} \cdot \mathrm{kg}^{-1} \cdot \mathrm{min}^{-1}\right.$, $n=5)$, respectively. ${ }^{*} p<0.02$

pathways other than the insulin receptor [10]. An inhibitory effect of $\mathrm{C}$ peptide on hepatic glucose production is theoretically possible but it appears less likely since hepatic effects of $\mathrm{C}$ peptide have not been reported. In addition, C-peptide infusion in healthy subjects fails to inhibit splanchnic glucose output (Wahren, unpublished observation). Nevertheless, an inhibitory effect of $\mathrm{C}$ peptide on hepatic glucose production in the diabetic state cannot be ruled out. A renal effect of $\mathrm{C}$ peptide on glucose turnover is unlikely; $\mathrm{C}$ peptide is known to diminish glomerular hyperfiltration and urinary protein excretion in diabetic animals [20] and in Type I diabetic patients $[2,4]$ but does not increase glucosuria.
These findings support and extend the results from a previous study in which supraphysiological concentrations of human $\mathrm{C}$ peptide were found to augment GDR in anaesthetized diabetic but not in normal rats [21]. In that study the specificity of the $C$ peptide effect was established by the finding that a peptide with the same amino acid residues as $\mathrm{C}$ peptide, which had been assembled in random order, had no effect on GDR or MCR [21]. Infusion of homologous $\mathrm{C}$ peptide to physiological concentrations in Type I diabetic patients results in a stimulation of wholebody glucose utilization by $20-25 \%$ [2]. In clinical studies involving $\mathrm{C}$-peptide treatment for 1 month, however, no clear-cut effect on blood glucose concentrations were seen [4], indicating that the C peptide's effect on glucose utilization may be less pronounced in humans than in the rat. Consistently no further stimulation of glucose utilization has been observed when C-peptide concentrations are increased above the physiological range and no effects of $\mathrm{C}$ peptide observed in healthy subjects or animals $[3,21]$. There is no immediate explanation for this but it is compatible with the hypothesis that $\mathrm{C}$ peptide receptors on cell membranes are relatively few and show high affinity binding, thereby reaching saturation at low C-peptide concentrations. Experimental support for this formulation has recently been obtained with the finding of specific binding of $\mathrm{C}$ peptide to cell membranes, showing saturation of binding in the low nanomolar concentration range [22].

The rat's two different $C$ peptides differ only in the two amino acids in the middle segment of the molecule [9]. When C peptide I and II were given in separate experiments their effects with regard to stimulation of glucose utilization were found to be almost identical (Tables 3,4$)$. This agrees with previous observations 
that $\mathrm{C}$ peptide I and II exert similar effects on the $\mathrm{Na}^{+}, \mathrm{K}^{+}-$ATPase activity of renal tubular segments [7].

Evidence from studies of isolated muscle tissue in vitro show that the stimulatory effect of C-peptide on glucose transport by muscle is independent of insulin; blockade of the insulin receptor does not diminish muscle glucose uptake induced by $\mathrm{C}$ peptide [10]. Several studies both in vitro and in vivo have shown that muscle glucose transport can be stimulated by $\mathrm{NO}$ and that NO-synthase in its neuronal and endothelial isoforms are expressed in skeletal muscle $[12,13,23,24]$. Moreover, C peptide is reported to stimulate NO-synthase of aortic endothelial cells [8]. Prompted by these considerations we examined the influence of L-NMMA, a known inhibitor of NO-synthase, on stimulation of whole-body glucose utilization induced by $\mathrm{C}$ peptide in the present group of diabetic rats (Fig.3). The results indicate that a major proportion, if not all of the C-peptide stimulation of glucose utilization, occurs through a NO-mediated pathway. This effect on glucose utilization is most likely independent of possible vascular effects of LNMMA, since it is also observed in isolated muscle tissue under in vitro conditions [23]. This view is further supported by the findings for combined LNMMA and adenosine treatment (Fig.3), in which adenosine treatment served to elicit compensatory vasodilation to correct for L-NMMA-induced reductions in blood flow. Nevertheless, our findings regarding C-peptide and L-NMMA effects on glucose utilization should be regarded as preliminary.

Acknowledgements. We thank Dr. Yanaihara N. and Dr. Luo W-Q in Yanaihara Institute, Shizuoka, Japan, for excellent technical support. This study is, in part, supported by Suzuken Memorial Foundation.

\section{References}

1. Kitabchi AE (1970) The biological and immunological properties of pork and beef insulin, proinsulin and connecting peptides. J Clin Invest 49: 979-987

2. Johansson B-L, Sjöberg S, Wahren J (1992) The influence of human C-peptide on renal function and glucose utilization in Type 1 (insulin-dependent) diabetic patients. Diabetologia 35 : $121-128$

3. Johansson B-L, Linde B, Wahren J (1992) Effects of C-peptide on blood flow, capillary diffusion capacity and glucose utilization in the exercising forearm of Type1 (insulin-dependent) diabetic patients. Diabetologia 35: 1151-1158

4. Johansson B-L, Kernell A, Sjöberg S, Wahren J (1993) Influence of combined C-peptide and insulin administration on renal function and metabolic control in diabetes Type 1. J Clin Endocrinol Metab 77: 976-981

5. Johansson B-L, Borg K, Fernqvist-Forbes E, Odergren T, Remahl S, Wahren J (1996) C peptide improves autonomic nerve function in patients with type 1 diabetes. Diabetologia 39: 687-695
6. Forst T, Kunt T, Pfützner A, Beyer J, Wahren J (1998) New aspects on biological activity of $\mathrm{C}$ peptide in IDDM patients. Exp Clin Endocrinol Diabetes 106: 270-276

7. Ohtomo Y, Aperia A, Sahlgren B, Johansson B-L, Wahren J (1996) C-peptide stimulates rat renal tubular $\mathrm{Na}^{+} \mathrm{K}^{+}$-ATPase activity in synergism with neuropeptide Y. Diabetologia 39: 199-205

8. Kunt T, Forst T, Closs E et al. (1998) Activation of endothelial nitric oxide synthase (eNOS) by C-peptide. Diabetologia 41[Suppl 1] A176

9. Tager HS, Steiner DF (1996) Primary structures of the proinsulin connecting peptides of the rat and horse. $\mathrm{J}$ Biol Chem 247: 7936-7941

10. Zierath JR, Handberg A, Tally M, Wallberg-Henriksson H (1996) C-peptide stimulates glucose transport in isolated human skeletal muscle independent of insulin receptor and tyrosine kinase activation. Diabetologia 39: 306-313

11. Shashkin PN, Jiao Y, Westerblad H, Katz A (1997) C peptide does not alter carbohydrate metabolism in isolated mouse muscle. Am J Phyisol 272:E245-E247

12. Etgen GJ, Fryburg DA, Gibbs EM (1997) Nitric oxide stimulates skeletal muscle glucose transport through a calcium/contraction- and phosphatidylininositol-3 kinase-independent pathway. Diabetes 46: 1915-1919

13. Young ME, Radda GK, Leighton B (1997) Nitric oxide stimulates glucose transport and metabolism in rat skeletal muscle in vitro. Biochem J 322: 223-228

14. Oshida Y, Ohsawa I, Sato J, Sato Y (1993) Effects of adrenodemedullation on in vivo insulin-stimulated glucose utilization in relation to glycolysis in rat peripheral tissue. Endocr J 40: 99-106

15. Yang W-P, Oshida Y, Wu W, Sato J, Ohsawa I, Sato Y (1995) Effect of daily voluntary running on in vivo insulin action in rat skeletal muscle and adipose tissue as determined by the microdialysis technique. Int J Sports Med 16: 99-104

16. Gardiner SM, Kemp PA, March JE, Bennett T (1995) Cardiac and regional haemodynamics, inducible nitric oxide synthase (NOS) activity, and the effects of NOS inhibitors in conscious, endotoxaemic rats. Br J Pharm 116: 2005-2016

17. Karimi A, Ball KT, Power GG (1996) Exogenous infusion of adenosine depresses whole body $\mathrm{O}_{2}$ use in fetal/neonatal sheep. J Appl Physiol 81: 541-547

18. Engvall E, Perlmann P (1971) Enzyme-linked immunosorbent assay (ELISA). Quantitative assay of immunoglobulin G. Immunochemistry 8: 871-874

19. Johansson B-L and Pernow J (1999) C peptide potentiates the vasoconstrictor effect of neuropeptide $\mathrm{Y}$ in insulin-dependent diabetic patients. Acta Physiol Scand 165: 39-44

20. Sjöquist M, Huang W, Johansson B-L (1998) Effects of C peptide on renal function at the early stage of experimental diabetes. Kidney Int 54: 758-764

21. Wu W, Oshida Y, Yang W-P et al. (1996) Effect of C-peptide administration on whole body glucose utilization in STZ-induced diabetic rats. Acta Physiol Scand 156: 253-258

22. Wahren J, Rigler R, Pramanik A et al. (1999) Specific binding of proinsulin C-peptide to human cell membranes. Eur J Endocrinol 140[Suppl 1] 21

23. Roy D, Perreault M, Marette A (1998) Insulin stimulation of glucose uptake in skeletal muscles and adipose tissues in vivo is NO dependent. Am J Physiol 274:E692-E699

24. Balon TW, Nadler JL (1997) Evidence that nitric oxide increases glucose transport in skeletal muscle. J Appl Physiol 82: 359-363 